УДК 903.23

https://doi.org/10.24852/2587-6112.2021.3.148.155

\title{
ЭТНОКУЛЬТУРНАЯ КАРТА ЮЖНОГО ПРЕДУРАЛЬЯ В ПЕРИОД МЕЖДУ ВЕНГРАМИ И МОНГОЛАМИ
}

(C) 2021 г. В.А. Иванов

Статья посвящена характеристике этнокультурной ситуации в Южном Предуралье в X-XI вв. по археологическим данным. По мнению автора, в лесах региона продолжала сохраняться этническая доминанта угорского населения - носителей петрогромской и постпетрогромской культур, занявших эту территорию после ухода древних угров-мадьяр на запад. Они составляли западную часть этнокультурного ареала (ЭКА) угорских племен Зауралья и Западной Сибири. В это же время в степях Южного Предуралья кочуют племена огузов и печенегов. Волжская Булгария, переживавшая в указанное время период своего наивысшего социально-экономического и политического подъема, активно осваивала лесные пространства Прикамья и Предуралья. Поэтому объективно она сыграла роль ареалообразующего фактора угорских племен региона. Что касается кочевников Степного Предуралья - огузов и печенегов - то, по имеющимся археологическим материалам, культурное влияние Волжской Булгарии на них не прослеживается.

Ключевые слова: археология, угры, огузы, печенеги, Волжская Булгария, постпетрогромский тип, аридизация, гумидизация.

\section{ETHNIC-CULTURAL MAP OF THE SOUTHERN PRE-URALS REGION IN THE PERIOD BETWEEN THE HUNGARIANS AND THE MONGOLS}

\section{A. Ivanov}

The paper characterizes the ethnic-cultural situation in the Southern Cis-Urals in the $10^{\text {th }}-11^{\text {th }}$ centuries on the basis of archaeological data. In the author's opinion, the ethnic dominant of the Ugric population remained in the forests of the region - the carriers of the Petrogrom and post-Petrogrom cultures, who occupied this territory after the migration of the ancient Magyar Ugrians to the west. They formed the western portion of the ethnic-cultural area (ECA) of the Ugric tribes of the Trans-Urals and Western Siberia. At the same time, the tribes of the Oguz and Pechenegs roamed the steppes of the Southern Cis-Urals. Volga Bolgaria, which then experienced the period of its highest socio-economic and political upsurge, was actively developing the forest areas of the Kama region and the Pre-Urals. Therefore, it objectively played the role of the area-forming factor for the Ugric tribes of the region. As for the nomads of the Steppe Cis-Urals - the Oguz and Pechenegs - no cultural influence of Volga Bolgaria on them has been traced on the basis of the available archaeological materials.

Keywords: archaeology, Ugrians, Oguz, Pechenegs, Volga Bolgaria, post-Petrogrom type, aridization, humidization.

Содержание этнокультурных процессов в Южном Предуралье в эпоху раннего Средневековья в настоящее время представляется наиболее полно освещенным в двух контекстах: Уральская прародина древних угровмадьяр в VIII-IX вв. (проблема Magna Hungaria) (Белавин и др., 2015) и население региона в составе Золотой Орды в XIII-XIV вв. (Иванов, 2016). Промежуток между этими двумя хронологическими периодами в восприятии исследователей региона разбивается на два сюжета, синхронных, но друг от друга независимых. Это угры Предуралья в X-XIV вв. (Гарустович, 2015; Белавин, Иванов, 2016) и огузы и печенеги в степях Урало-Поволжья (Иванов и др., 2014).

Примечательно так же и то, что пребывание угров и тюркоязычных кочевников (огузов, печенегов, а затем и кыпчаков-половцев) в Южном Предуралье осуществлялось на фоне максимального роста территории Волжской Булгарии - единственного в Урало-Поволжье раннефеодального государства (Хузин, 2006, c. 44-50).

Цель настоящей статьи - проанализировать археологическую карту Южного Предуралья X-XIII вв., то есть того периода, когда древние мадьяры-венгры в основной своей массе уже ушли из региона («семь племен Хетумогер»), а до монгольского вторжения в Восточную Европу было ещё очень далеко ${ }^{1}$. И поскольку этнокультурная составляющая этой карты сейчас в общих чертах определена и не вызывает серьезных возражений у большинства современных исследователей, то результаты археолого-географического анали- 
за имеющихся археологических материалов могут внести дополнительную определенность и в этническую карту Урало-Поволжья в указанный период.

Прежде всего, следует дать характеристику той природно-климатической ситуации, которая имела место в Урало-Поволжском регионе в интересующий нас период. Она восстанавливается по данным палеопочвоведения и палинологии.

По этим данным, конец I - начало II тыс. н. э. для Урало-Поволжского региона были временем повышенной аридизации лесной ландшафтной зоны и гумидизации степной ${ }^{2}$. В климатическом контексте это уменьшение увлажненности с одновременным потеплением климата в лесах региона (сокращение количества осадков, понижение уровня грунтовых вод, высыхание болот и заболачивание озер 3 , сокращение северной и южной границ широколиственных лесов: северная сдвигается на юг, южная сдвигается к северу под натиском наступающей степи (Смирнова, Турубанова, 2003, с. 35; Аськеев И.В. и др., 2009, с. 70). Обозначить эти границы достаточно сложно. Хотя сейчас известны по крайней мере две точки - городище Уфа II в Предуралье и Казань на Средней Волге, показывающие, что в разных концах Урало-Поволжского региона в рассматриваемое время наблюдается одна и та же ландшафтная ситуация - пограничная зона между широколиственными лесами и лесостепью (Аськеев И.В. и др., 2009, с. 70; Курманов, 2015).

В степях региона в это же время (рубеж IX-X вв.) ситуация приближается к современной (примерно середина XX в.), а затем изменяется в сторону повышения гумидизации (Якимов и др., 2007, с. 195).

Археологическая карта Прикамья и Предуралья в означенный период выглядит следующим образом: лесная зона региона продолжает оставаться ареалом расселения угорских племен, оставивших памятники ломоватовско-поломского и петрогромско-мрясимовского типов. Отличительной особенностью материальной культуры этих памятников является керамика со шнуро-гребенчатой орнаментацией.

С точки зрения археологической морфологии, керамика со шнуро-гребенчатой орнаментацией не представляет типологического «монолита». Так, сосуды ломоватовско-поломских памятников лесного Прикамья хотя и отличаются разнообразием керамических форм, но преобладают среди них сосуды низких пропорций с широкой отогнутой наружу горловиной, тогда как среди неволинской керамики явно доминируют сосуды с прямыми шейками (Белавин и др., 2009, с. 125-145).

В отличие от них для «постпетрогромской» керамики Волжской Булгарии характерны «гибридные» сосуды, сочетающие в себе высокую цилиндрическую шейку, посаженную на приплюснутое тулово (Казаков, 2007, c. 52-55).

В наиболее «чистом» виде петрогромские/ постпетрогромские сосуды представлены в курганах «мрясимовского» типа на Южном Урале - Мрясимовских, Каранаевских, Идельбаевских, Бакалинских (рис. 1).

Различается и погребальный обряд могильников указанных типов. Так, в Прикамье и в начале II тыс. н. э. сохраняется обряд захоронения в бескурганных могильниках. Яркий тому пример Кишертский, Огурдинский, Рождественский могильники (Белавин, Крыласова, 2012, с. 205-206; 2009, с. 92-102; Пастушенко, 2005-2006).

Погребальный обряд могильников «мрясимовского типа», локализованных в лесах Южного Предуралья, суммарно характеризуется следующими признаками: захоронения под земляными насыпями, в большинстве случаев (около 60\% от 51 кургана) содержащие по одной могиле; 47\% известных курганов содержали в насыпи следы ритуального конского жертвоприношения: черепа, кости ног лошади; почти в половине всех исследованных погребений - остатки заупокойной пищи (конины) в виде плечевых костей лошади, уложенных в изголовье могилы или у ног погребенного. В одном случае (Мрясимовский могильник, к. 21) рядом с человеческим захоронением в отдельной яме находилось захоронение целой туши взнузданного и оседланного коня. Абсолютно преобладает ориентировка погребенных в западном секторе. Погребальный инвентарь состоит из предметов конской упряжи, оружия и женских украшений. Глиняные сосуды помещали только в женские и детские могилы (Гарустович, 2011; 2015, с. 185-187).

В первой четверти IX в. северо-западная оконечность Кунгурско-Месягутовской лесостепи обезлюдила. Племена неволинской археологической культуры в массовом порядке покидают эту территорию. Часть их ушла севернее, на берега Чусовой и Обвы, где их присутствие фиксируется по т. н. «постневолинской» керамике (т. е. посуде с сохранением неволинских черт, но в слоях $\mathrm{X}$ в.). Часть 


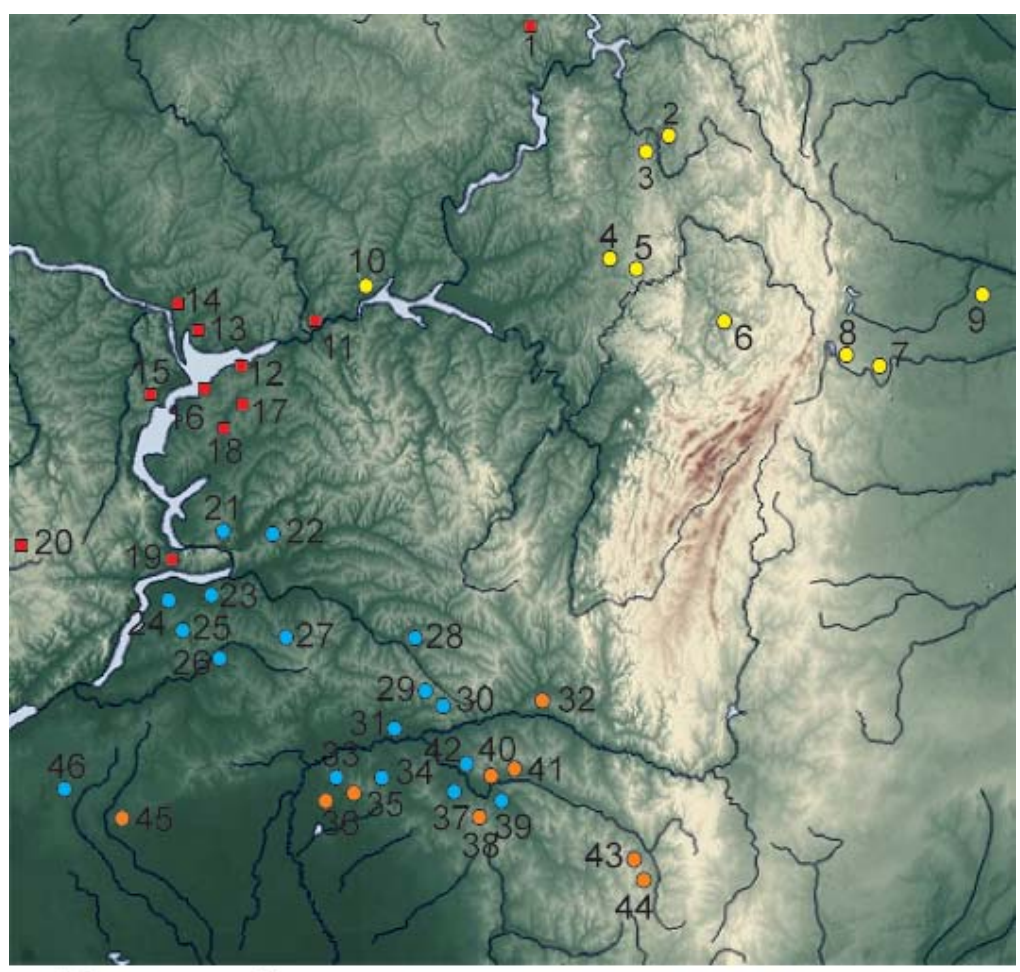

Условные обозначения:

- - I; О - II; О - III; О - IV

Рис. 1. Карта памятников X-XI вв. в Урало-Поволжье.

Условные обозначения: I - города Волжской Булгарии (по Ф.Ш.Хузину); II - могильники «постпетрогромского типа» (угры) (по Г.Н.Гарустовичу); III - курганы печенегов; IV - курганы огузов.

1 - Рождественское (Афкула);(село Рождественск) 2 - Кишертский (д. Усть-Кишерть); 3 - «Селянино Озеро» (местность с таким же названием); 4 - Бакалинские (дер. Бакалы); 5 - Мрясимовский (с. Мрясимово);

6 - Каранаевский (с.Каранаево); 7 - Смолино (оз. Смолино); 8 - Миасские (город Миасс); 9 - Замараевский (д. Замараево); 10 - Тураевский (дер. Тураево); 11 - Алабуга (г. Елабуга); 12 - Джукетау; 13 - Кашан;

14 - Казань; 15 - Ошель; 16 - Болгар (Бряхимов); 17 - Биляр; 18 - Сувар; 19 - Муромский; 20 - Юлувское (Буртас?); 21 - «Золотая Нива» (совхоз «Золотая Нива»); 22 - Васильевский; 23 - Кировский II (совхоз им. Кирова); 24 - Красный Октябрь (свх. «Красный Октябрь»); 25 - Осинковский (дер. Осинки); 26 -

Александровский (сел. Александровка); 27 - Волчанское (дер. Волчанка); 28 - Сорочинское (гор. Сорочинск); 29 - Яман (с. Яман); 30 - Красный (пос. Красный); 31 - Рубежинский (пос. Рубежинский); 32 - Алебастровая гора (местность Алебастровая гора); 33 - Челкар III (озеро Челкар/Шалкар); 34 - Лебедевка (пос. Лебедевка); 35 - Челкар II, IV, V; 36 - Челкар ((озеро Челкар/Шалкар); 37 - Покровский (дер. Покровка); 38 - Болгарка I (дер. Болгарка); 39 - Буранный (пос. Буранный); 40 - Тамар-Уткуль (с. Тамар-Уткуль); 41 - Увак (пос. Увак); 42 - Пчельник (местность Пчельник); 43 - Жаман-Каргала (пос. Жаман-Каргала); 44 - Жаман-Каргала I ((пос. Жаман-Каргала); 45 - хутор Ст.Разина; 46 - Кураевский сад (колония Кураевский сад)

Fig. 1. Map of $10^{\text {th }}-11^{\text {th }}$ century sites in the Ural-Volga region.

Legend: I - towns of Volga Bolgaria (after F.Sh. Khuzin); II - burial grounds of the "post-Petrogrom type" (the Ugrians) (after G.N. Garustovich); III - barrows of the the Pechenegs; IV - barrows of the Oguz. 1 - Rozhdestvensk (Afkula); 2 - Kishert'; 3 - "Selyanino Ozero"; 4 - Bakaly; 5 - Mryasimovo; 6 - Karanaevo; 7 - Smolino;

8 - Miass; 9 - Zamaraevo; 10 - Turaevo; 11 - Alabuga; 12 - Juketau; 13 - Kashan; 14 - Kazan; 15 - Oshel'; 16 - Bolgar (Bryakhimov); 17 - Bilyar; 18 - Suvar; 19 - Muromsky; 20 - Yuluvo (Burtas?); 21 - "Zolotaya Niva";

22 - Vasilievsky; 23 - Kirovsky II; 24 - Krasny Oktyabr'; 25 - Osinki; 26 - Alexandrovka; 27 - Volchanka;

28 - Sorochinsk; 29 - Yaman; 30 - Krasny; 31 - Rubezhinsky; 32 - Alebastrovaya gora; 33 - Chelkar III; 34 - Lebedevka; 35 - Chelkar II, IV, V; 36 - Chelkar; 37 - Pokrovka; 38 - Bolgarka I; 39 - Buranny; 40 - Tamar-Utkul; 41 Uvak; 42 - Pchelnik; 43 - Zhaman-Kargala; 44 - Zhaman-Kargala I; 45 - Khutor Stepana Razina; 46 - Kuraevsky Sad

переселилась в Волжскую Булгарию, где это население, благодаря своеобразной керамике с резной орнаментацией, хорошо заметно (Казаков, 2007, с. 51-59). Большая часть «неволинцев», скорее всего, ушла вместе с другими угро-мадьярскими племенами на запад.
Степная зона Южного Предуралья в конце IX - первой половине XI вв. становится ареалом расселения тюркоязычных кочевников огузов и печенегов. Их библиография в регионе обширна, поэтому здесь ограничусь общей, суммарной характеристикой археологической культуры указанных племен: 
Для огузов - впускные погребения в насыпи более ранних курганов, по одному в каждой насыпи, в простых прямоугольных могилах, иногда перекрытых деревом, в позе вытянуто на спине, головой на запад, в сопровождении шкуры взнузданного и оседланного коня, уложенной на перекрытие над человеком, с богато украшенным конским изголовьем, прямоугольными подпружными пряжками, поясами с цельнолитыми овальнорамчатыми пряжками и орнаментированными наконечниками, птицевидными подвесками, копоушками, декоративными дисками и перстнями салтовского типа.

Для печенегов - основные и впускные погребения, иногда по два под одной насыпью, в простых могилах, в позе вытянуто на спине, головой на запад, встречаются дощатые гробы, шкура коня - на дне могилы слева от человека, конь взнуздан и оседлан, часто в могилах встречаются кости барана, конская сбруя состоит из удил без перегиба и стремян различных типов, украшена сбруя прорезными бубенчиками, вместе с погребенным лук со срединными костяными накладками, пояс с треугольнорамчатой, прямоугольной или лировидной пряжкой, глиняный лепной кувшин или плоскодонный горшок (Иванов и др., 2014, с. 124-136).

География памятников указанных типов это зона предуральско-заволжских типчаковоковыльных степей, между Самарской Лукой на севере и границами Прикаспийских полупустынь на юге.

В районе Самарской Луки кочевья печенегов вплотную подходили к южным рубежам домонгольской Волжской Булгарии, восточные границы которой проходили в X-XI вв. по низовьям рр. Ик, Иж, верховьям Зая, Шешмы и Большого Черемшана. То есть по западным склонам Бугульминско-Белебеевской возвышенности (Хузин, 2006а, с. 132-136).

Итак, этнокультурная ситуация в УралоПоволжском регионе в X-XI и XII вв. в общем ясна: лесное Прикамье и Предуралье являлись ареалом расселения носителей культур с гребенчато-шнуровой керамикой, в X-XII вв. обитавших по обе стороны Уральского хребта. Если исходить из опубликованных карт, то памятники с гребенчато-шнуровой керамикой лесного Прикамья и Предуралья (петрогромского или предчияликского типа) составляли западную периферию петрогромско-юдинского историко-культурного горизонта VIII-XV вв. (Боталов, 2016, с. 512, рис. 18).
В свое время нами было выдвинуто предложение рассматривать эти памятники как часть этнокультурного ареала (ЭКА) культур со штампо-гребенчатой керамикой лесного и лесостепного Зауралья и Западной Сибири (культур угорских) (Гарустович, Иванов, 1992, с. 24). Понятие «этнокультурный ареал» (ЭКА) сформулировано без малого 40 лет тому назад Г.Д. Савиновым. Поскольку современные исследователи в большинстве своем в своих работах равно не используют ни того, ни другого понятия, напомню определение ЭКА, данное его автором: «Под этнокультурным ареалом (ЭКА) понимается территория, на которой сложилась определенная этнокультурная общность... С точки зрения археологии ЭКА представляет собой атрибут археологической культуры, точнее, еe пространственно-культурное выражение на определенном хронологическом срезе (выделено мной - aвm. $)^{4} \ldots$ В пределах каждого ЭКА возможно как сплошное, так и дисперсное расселение носителей данного этнонима (политонима), узкая этническая принадлежность которых (по языку, происхождению и т. д.) может быть различной. В силу последнего обстоятельства на одной территории в одно и то же время могут быть представлены археологические памятники, различающиеся по деталям погребального обряда, приемам орнаментации керамики и другим наиболее традиционным культурным элементам. Однако в рамках одного этносоциального объединения у них складываются общие культурные особенности, отраженные в археологических материалах, которые и являются основанием для выделения ЭКА» (Савинов, 1984, с. 48).

Население северной части прикамскопредуральской периферии угорского ЭКА в X-XII вв. подпадает под сильное культурноэкономическое воздействие Волжской Булгарии, вступившей в это время в период своего наивысшего подъема. По определению Р.Г. Кузеева, именно территория этого государства, плотно заселенная, население которой характеризовалось более высокой культурой, составляла в указанное время основу Волго-Уральской историко-этнографической области (ИЭО): «Именно здесь на относительно компактной площади протекал первоначально наиболее активный процесс финно-угорско-тюркского этнокультурного взаимодействия, расширяясь постепенно на периферию этой зоны. На этой же территории с выгодным географическим положением на крупных водных артериях, в благоприят- 
ных экологических условиях для земледельческого хозяйства сформировалось первое феодальное государство в регионе - Волжская Болгария, сыгравшая роль крупного ареалообразующего и этноконсолидирующего фактора для всего региона (выделено мной - авт.)» (Кузеев, Иванов, 1984, с. 5).

В первую очередь это проявилось в проникновении булгар далеко на север лесного Прикамья и распространении элементов булгарской культуры среди местного населения (археологический комплекс у с. Рождествено на р. Обва - Древняя Афкула, городище Иднакар на Чепце и др.) (Белавин, Крыласова, 2008; История Удмуртии..., 2007, c. 271).

Чего не наблюдается в отношении кочевников степей Заволжья и Южного Предуралья - огузов и печенегов. От угров лесного и лесостепного Предуралья их отделяли отроги Бугульминско-Белебеевской возвышенности. С точки зрения хозяйственного освоения для эпохи раннего Средневековья эта территория ни для земледельцев, ни для кочевников ценности не представляла по целому ряду природно-географических условий. Во-первых, ее абсолютная высота колеблется от 200 до 480 м, причем повышается именно к югу, к степи. Во-вторых, в силу этого обстоятельства снег на ее склонах сохраняется до начала мая. В-третьих, поверхность возвышенности сильно изрезана руслами стекающих с нее рек и оврагами, на склонах которых трава уже к началу августа выгорает ${ }^{5}$.

Поэтому Бугульминско-Белебеевская возвышенность, географически расположенная между миром полуоседлых угров лесной зоны Предуралья, оседло-земледельческим и торгово-ремесленным населением Волжской Булгарии и кочевниками степного Заволжья и Предуралья, являлась не интегрирующим компонентом Волго-Уральской ИЭО (по Р.Г. Кузееву), а буферной зоной.
Что и отразилось в незначительности археологически фиксируемых признаков культурных (в широком смысле этого слова) контактов между волжскими булгарами, огузами и печенегами в X-XI вв. В частности, это хорошо прослеживается на материале костюмных комплексов, среди аксессуаров которых ни у печенегов, ни у огузов булгарских элементов практически не выявлено (Иванов, Крыласова, 2006, с. 136-140).

Итак, некоторые выводы: как ареалообразующий фактор Волжская Булгария наиболее отчетливо проявляла себя в лесном Прикамье и Среднем Поволжье. Кроме упомянутой выше «Касабе Афкула» в Прикамье, следует ещё упомянуть и о распространенной здесь группе украшений XI-XIII вв., трактуемых как булгарский импорт (Подосенова, 2009, c. 14). Многочисленные изделия булгарского производства - посуда, ювелирные изделия, бронзовые замки - обнаружены и на древнемарийских памятниках IX-XIII вв. Ветлужско-Вятского междуречья (Никитин, Никитина, 2004, с. 61).

Культурные контакты булгар с прикамскоприуральскими уграми, создателями памятников постпетрогромского типа, фиксируются всеми исследователями, в том числе и в виде широкого расселения «постпетрогромцев» по территории Волжской Булгарии (Гарустович, 2015, с. 184; Казаков, 2007, с. 51-59).

Ничего подобного не наблюдается относительно кочевников Степного Предуралья огузов и печенегов. Исследователи керамики Волжской Булгарии выделяют в ее составе огузо-печенежскую керамику (керамика IX, Х и XIII этнокультурных групп) (Хлебникова, 1984, с. 225-230; Кокорина, 2002, с. 33). Однако ее появление на территории этого государства может быть связано с событиями середины XI в. - нашествием половцев-кипчаков и изгнанием печенегов и огузов из степей Южного Предуралья.

\section{Примечания:}

${ }^{1}$ Конечно, если подходить со всей строгостью, то временные рамки указанного периода должны определяться второй половиной IX и первой половиной XIII вB. Но пока разработанная хронологизация имеющегося археологического материала не дает возможности выделять хронологические комплексы, выступающие в роли календарных реперов для того или иного столетия.

${ }^{2}$ В данном случае понятие «повышенная» приводится относительно условий примерно середины ХХ в. (Демкин, Демкина, 1999, с. 368, рис. 2).

3 Для севера Восточной Европы - наступление т.н. «климатического оптимума» (Клименко, 2003, с. 14; Клименко и др., 2012, с. 144).

${ }^{4}$ Как мы видим, в этом плане ЭКА и ИКГ - понятия равнозначные (Боталов, 2016, с. 468).

5 Личные наблюдения автора в течение нескольких лет. 


\section{ЛИТЕРАТУРА}

Аськеев И.В., Аськеев О.В., Галимова Д.Н. Природная среда и человек в Волго-Камье и Предуралье (поздний палеолит - средневековье) // Среднее Поволжье и Южный Урал: человек и природа в древности / Отв. ред. М.Ш. Галимова. Казань: Фэн, 2009. С. 32-112.

Белавин А., Данич А., Иванов В. Древние мадьяры в Предуралье // Фодор И. Венгры: древняя история и обретение родины. Пермь: ООО «Типография «ЗЕБРА», 2015. С. 101-128.

Белавин А.М., Иванов В.А. Население Западного Приуралья в X-XIV вв. // История татар Западного Приуралья. Т.І. Кочевники Великой степи в Приуралье. Татарские средневековые государства. / Ред. P.С. Хакимов. Казань: Институт истории им. Ш.Марджани АН РТ, 2016. С. 118-127.

Белавин А.М., Иванов В.А., Крыласова Н.Б. Угры Предуралья в древности и средние века. Уфа: Вагант, 2009. 285 с.

Белавин А.М., Крыласова Н.Б. Древняя Афкула: археологический комплекс у с. Рождественск. Пермь: Перм. гос. пед. ун-т., 2008. 603 с.

Белавин А.М., Крыласова Н.Б. Огурдинский могильник. Пермь: ПГГПУ, 2012. 259 с.

Боталов С.Г. Историко-культурные горизонты в эпоху раннего железного века и средневековья степного Зауралья // Археология Южного Урала. Лес, лесостепь (проблемы культурогенеза). / Серия «Этногенез уральских народов». Челябинск: Рифей, 2016. С. 468-541.

Гарустович Г.Н. Погребальный обряд Бакалинского курганного могильника эпохи средневековья // УАВ. Вып. 11. Уфа: Гилем, 2011. С. 80-95.

Гарустович Г.Н. Чияликская археологическая культура эпохи средневековья на Южном Урале. // УАВ. 2015. Вып. 15. С. 181-198.

Гарустович Г.Н., Иванов В.А. Ареал расселения угров на Южном Урале и в Приуралье во второй половине I - начале II тыс. н.э. // Проблемы этногенеза финно-угорских народов Приуралья / Отв. ред. Р.Д. Голдина. Ижевск: Удмуртский университет, 1992. С. 17-31.

Демкин В.А., Демкина Т.С. Археологическое почвоведение: новое направление в изучении древней и средневековой истории природы и общества// Археология Волго-Уральского региона в эпоху бронзового, раннего железного веков и средневековья. / Отв. ред. А.С. Скрипкин. Волгоград: Издательство ВолГУ, 1999. С. 343-368.

Иванов В.А. Кочевое население Улуса Джучи // Золотая Орда в мировой истории / Отв. ред.: И. Миргалеев, Р. Хаутала. Казань: ИИ им. Ш.Марджани АН РТ, 2016. С. 541-551.

Иванов В.А., Гарустович Г.Н., Пилипчук Я.В. Средневековые кочевники на границе Европы и Азии. Уфа: Изд-во БГПУ, 2014. $396 \mathrm{c.}$

Иванов В.А., Крыласова Н.Б. Взаимодействие леса и степи Урало-Поволжья в эпоху средневековья (по материалам костюма). Пермь, 2006. 162 с.

История Удмуртии: С древнейших времен до XV в. / Под ред. М.Г. Ивановой.Ижевск, 2007. 304 с.

Казаков Е.П. Волжские болгары, угры и финны в IX-XIV вв.: проблемы взаимодействия. Казань: Институт истории АН РТ. 2007. 208 с.

Клименко В.В. Климат и история в средние века // Восток (Oriens). 2003. №1. С. 5-41.

Клименко В.В., Мацковский В. В., Пахомова Л. Ю. Колебания климата высоких широт и освоение Северо-Восточной Европы в средние века // История и современность. 2012. № 2. С. 130-163.

Кокорина Н.A. Керамика Волжской Булгарии второй половины XI - начала XV веков (к проблеме преемственности булгарской и булгаро-татарской культур). Казань: ИИ АН РТ, ИА РАН, 2002. 383 с.

Кузеев Р.Г., Иванов В.А. Этнические процессы в Волго-Уральском регионе в V-XVI веках и проблема происхождения чувашского этноса // Болгары и чуваши / Ред. Димитриев В.Д., Прохорова В.А.Чебоксары: ЧувНИИ, 1984. С. 3-22.

Курманов Р.Г. Изучение сукцессий растительных сообществ городища Уфа II методом споровопыльцевого анализа // Вестник археологии, антропологии и этнографии. 2015. № 4 (31). С. 175-184.

Никитин В.В. Никитина Т.Б. К истокам марийского искусства. Йошкар-Ола: МарНИИЯЛИ, 2004. $152 \mathrm{c}$.

Пастушенко И.Ю. Кишертский могильник в бассейне реки Сылвы // Finno-Ugrica. 2005-2006. №9. C. $40-70$.

Подосенова Ю.А. Височные украшения населения Пермского Предуралья в эпоху средневековья. Автореф. дисс. канд. ист. наук. Казань, 2009. 27 с. 
Савинов Д.Г. Этнокультурные ареалы Южной Сибири в эпоху раннего средневековья // Проблемы археологии степей Евразии. Советско-венгерский сборник / Отв. ред. А. И. Мартынов. Кемерово: Кемеров гос. ун-т, 1984. С. 46-54.

Смирнова O.В., Турубанова С.А. Формирование и развитие восточноевропейских широколиственных лесов в голоцене // Бюллетень Московского общества испытателей природы. Отдел биологический. 2013. № 118 (2). С. 32-40.

Хлебникова Т.А. Керамика памятников Волжской Болгарии. К вопросу об этнокультурном составе населения. М.: Наука, 1984. 241 с. $583 \mathrm{c.}$

Хузин Ф.Ш. Ранние булгары и Волжская Булгария (VIII - начало XIII в.). Казань: Фолиантъ, 2006.

Хузин Ф.Ш. Булгарское государство: образование, территория и население. Территория // История татар с древнейших времен. В семи томах. Т. II. Влжская Булгария и Великая Степь. степь / Отв. ред. Ф.Ш. Хузин. Казань: РухИЛ,, 2006а. С. 132-136.

Якимов А.С., Дёмкин В.А., Алексеев А.О. Природные условия степей Нижнего Поволжья в эпоху средневековья (VIII-XIV вв. н.э.). М.: НИА - Приода. Фонд «Инфосфера», 2007. 228 с.

\section{Информация об авторе:}

Иванов Владимир Александрович, доктор исторических наук, профессор, Башкирский государственный педагогический университет им.М.Акмуллы (Уфа, Россия); ivanov-sanych@inbox.ru

\section{REFERENCES}

Askeev, I. V., Askeev, O. V., Galimova, D. N. 2009. In Galimova, M. Sh. (ed.). Srednee Povolzh'e i Iuzhnyi Ural: chelovek i priroda v drevnosti (The Middle Volga Region and the Southern Urals: People and Nature in Prehistory). Kazan: "Fen" Publ., 32-112 (in Russian).

Belavin, A., Danich, A., Ivanov, V. 2015. In Fodor, I. (ed.). Vengry: drevniaia istoriia i obretenie rodiny (Hungarians: Ancient History and the Conquest of the Homeland). Perm: "Zebra" Publ., 101-128 (in Russian).

Belavin, A. M., Ivanov, V. A. 2016. In Khakimov, R. S. (ed.). Istoriia tatar Zapadnogo Priural 'ia (History of the Tatars of the Western Urals) I. Kazan: Institute of History named after Shigabuddin Mardzhani, Tatarstan Academy of Sciences, 118-127 (in Russian).

Belavin, A. M., Ivanov, V. A., Krylasova, N. B. 2009. Ugry Predural'ia v drevnosti i srednie veka (The Cis-Urals Ugric Peoples in the Antiquity and Middle Ages). Ufa: "Vagant" Publ. (in Russian).

Belavin, A. M., Krylasova, N. B. 2008. Drevniaia Afkula: arkheologicheskii kompleks u s. Rozhdestvensk (Ancient Afkula: the Archaeological Complex near the Rozhdestvensk Village). Perm: Perm State Pedagogical University (in Russian).

Belavin, A. M., Krylasova, N. B. 2012. Ogurdinskii mogil'nik (Ogurdino Burial Ground). Perm: Perm State Humanitarian Pedagogical University (in Russian).

Botalov, S. G. 2016. In Arkheologiia Iuzhnogo Urala. Les, lesostep' (problemy kul'turogeneza) (Archaeology of the Southern Urals. Forest, Forest-Steppe (issues of cultural genesis). Series: Ethnogenesis of Ural peoples. Cheliabinsk: "Riphean" Publ., 468-541 (in Russian).

Garustovich, G. N. 2011. In Ufimskii arkheologicheskii vestnik (Ufa Archaeological Herald) 11. Ufa: "Gilem" Publ., 80-95 (in Russian).

Garustovich, G. N. 2015. In Ufimskii arkheologicheskii vestnik (Ufa Archaeological Herald) 15. 181-198. (in Russian).

Garustovich, G. N., Ivanov, V. A. 1992. In Goldina, R. D. (ed.). Problemy etnogeneza finno-ugorskikh narodov Priural 'ia (Issues of Ethnic Genesis of the Cis-Urals Finno-Ugric Peoples). Izhevsk: Udmurt University, 17-31 (in Russian).

Demkin, V. A., Demkina, T. S. 1999. In Skripkin, A. S. (ed.). Arkheologiia Volgo-Ural'skogo regiona v epokhu bronzovogo, rannego zheleznogo vekov $i$ srednevekov'ia (Archaeology of the Volga-Ural Region in the Bronze Age, Early Iron Age and the Middle Ages). Volgograd: Volgograd State Universuty, 343-368 (in Russian).

Ivanov, V. A. 2016. In Mirgaleev, I. M., Khautala, R. (eds.). Zolotaia Orda v mirovoi istorii (The Golden Horde in world history). Kazan: Institute of History named after Shigabuddin Mardzhani, Tatarstan Academy of Sciences, 541-551 (in Russian).

Ivanov, V. A., Garustovich, G. N., Pilipchuk, Ia. V. 2014. Srednevekovye kochevniki na granitse Evropy $i$ Azii (Medieval Nomads on the Border between Europe and Asia). Ufa: Bashkir State Pedagogical University (in Russian). 
Ivanov, V. A., Krylasova, N. B. 2006. Vzaimodeistvie lesa i stepi Uralo-Povolzh'ia vepokhu srednevekov'ia (po materialam kostiuma)). (Interaction of the Forest and Steppe of the Ural-Volga Region in the Middle Ages (Based on Costume Materials)). Perm (in Russian).

Ivanova, M. G. 2007. (ed.). Istoriia Udmurtii: s drevneishikh vremen do XV v. (History of Udmurtia: From Antiquity to the $15^{\text {th }} \mathrm{c}$.). Izhevsk (in Russian).

Kazakov, E. P. 2007. Volzhskie bolgary, ugry i finny v IX-XIV vv.: problemy vzaimodeistviia (The Volga Bulgarians, the Ugrians and the Finns in $9^{\text {th }}-14^{\text {th }}$ Centuries: Issues of Interaction). Kazan: Institute for History named after Shigabuddin Mardzhani, Tatarstan Academy of Sciences of the Republic of Tatarstan (in Russian).

Klimenko, V. V. 2003. In Vostok (Oriens). 1. 5-41 (in Russian).

Klimenko, V.V., Matskovsky, V.V., Pakhomova, L.Yu. 2012. In Istoriia i sovremennost' (History and Contemporaneity) (2), 130-163 (in Russian).

Kokorina, N. A. 2002. Keramika Volzhskoi Bulgarii vtoroi poloviny XI-nachala XV vv.: K probleme preemstvennosti bulgarskoi i bulgaro-tatarskoi kul'tur (Ceramic Ware in Volga Bulgaria during the Second Half of the 11 th - Beginning of the 15th Centuries (on the Issue on Succession of the Bulgar and Bulgar-Tatar Cultures)). Kazan: Institute of History named after Shigabuddin Mardjani, Tatarstan Academy of Sciences; Russian Academy of Sciences, Institute of Archaeology (in Russian).

Kuzeev, R. G., Ivanov, V. A. 1984. In Dmitriev, V. D., Prokhorova, V. A. (eds.). Bolgary i chuvashi ( The Bolgars and the Chuvash). Cheboksary: Chuvashia Research Institute, 3-22 (in Russian).

Kurmanov, R. G. 2015. In Vestnik arkheologii, antropologii i etnografii (Bulletin of Archaeology, Anthropology and Ethnography) 31 (4), 175-184. (in Russian).

Nikitin, V. V. Nikitina, T. B. 2004. K istokam mariiskogo iskusstva (To the Origins of the Mari Art). Yoshkar-Ola: Mari Scientific and Research Language, Literature, History and Ethnography Institute (in Russian).

Pastushenko, I. Yu. 2005-2006. In Finno-Ugrica. 9, 40-70 (in Russian).

Podosenova, Yu. A. 2009. Visochnye ukrasheniia naseleniia Permskogo Predural'ia vepokhu srednevekov'ia (Temple Ornaments of the Perm Cis-Urals Population in the Middle Ages). Thesis of Diss. of Candidate of Historical Sciences. Kazan (in Russian).

Savinov, D. G. 1984. In Martynov, A. I. (ed.). Problemy arkheologii stepei Evrazii (Issues of the Archaeology of the Eurasian Steppes). Kemerovo: Kemerevo State Universiry, 46-54 (in Russian).

Smirnova, O. V., Turubanova, S. A. 2013. In Biulleten' Moskovskogo obshchestva ispytatelei prirody. Otdel biologicheskii (Bulletin of Moscow Society of Naturalists. Biological series) 118 (2). 32-40.

Khlebnikova, T. A. 1984. Keramika pamiatnikov Volzhskoi Bolgarii: (K voprosu ob etnokul'turnom sostave naseleniia) (Ceramic Ware ft he Volga Bolgaria Sites. On the Issue of Ethnic and Cultural Composition of the Population). Moscow: "Nauka" Publ. (in Russian).

Khuzin, F. Sh. 2006. Rannie bulgary $i$ Volzhskaia Bulgariia (VIII - nachalo XIII v.) (Early Bulgars and Volga Bulgaria ( $8^{\text {th }}-$ Early $13^{\text {th }}$ Centuries)). Kazan: "Foliant" Publ. (in Russian).

Khuzin, F. Sh. 2006. In Istoriya tatar s drevnejshih vremen (v semi tomah) (History of the Tatars since ancient times (in seven volumes). 2 Kazan: "RukhIL" Publ., 132-136. (in Russian).

Yakimov, A. S., Demkin, V. A., Alekseev, A. O. 2007. Prirodnye usloviia stepei Nizhnego Povolzh'ia v epokhu srednevekov'ia (VIII-XIV vv. n.e.) (Natural Conditions of the Steppes of the Lower Volga Region in the Middle Ages (8th-15th cc. AD). Moscow: "Inosfera" Publ. (in Russian).

\section{About the Author:}

Ivanov Vladimir A. Doctor of Historical Sciences, Professor. Bashkir State Pedagogical University, Oktyabrskoi revolutsii, 3A, Ufa, 450008, Russian Federation; ivanov-sanych@inbox.ru 